\title{
PHYTOCHEMICAL, ANTIBACTERIAL AND ANTIOXIDANT SCREENING OF Artemisia santolinifolia VARIOUS PARTS
}

\author{
Tabinda NOWSHEEN ${ }^{1}$ (D) , Ali HAZRAT ${ }^{1}$ (iD), Sayed Wadood Ali SHAH ${ }^{2}$ (D), \\ Shabana BIBI ${ }^{1}$, Afshan BEGUM ${ }^{3}$ (D), Muhammad MUKHTIAR ${ }^{4}$ (D) Adam KHAN $^{5}$ iD
}

\footnotetext{
${ }^{1}$ Department of Botany, University of Malakand, Chakdara, Pakistan.

2 Department of Pharmacy, University of Malakand, Pakistan.

3 Department of Chemistry, University of Peshawar, Pakistan.

${ }^{4}$ Department of Pharmacy, University of Poonch Rawalakot, Azad Kashmir, Pakistan.

${ }^{5}$ Department of Biological Sciences University of Lakki Marwat, KP, Pakistan.
}

Corresponding author:

Ali Hazrat

Email: ali.hazrat@uom.edu.pk

How to cite: NOWSHEEN, T., et al. Phytochemical, antibacterial and antioxidant screening of Artemisia santolinifolia various parts. Bioscience Journal. 2021, 37, e37061. https://doi.org/10.14393/BJ-v37n0a2021-54206

\begin{abstract}
The current study was carried out to explore the phytochemical, antioxidant potential and antibacterial activities of the crude methanolic extract of $A$. santolinifolia Turcz. Ex Besser. The antioxidant activity was carried out by using 1,1-diphenyl-2-picrylhydrazyl (DPPH) and 2,2'-azino-bis-3-ethylbenzthiazoline-6sulphonic acid (ABTS) assay, while methanolic extract displayed the highest scavenging activity (DPPH) was $61.31 \mu \mathrm{g} / \mathrm{ml}$ on Artemisia santolinifolia root and the lowest $(51.05 \mu \mathrm{g} / \mathrm{ml})$ was record for their leaves. Similarly, in (ABTS) the highest activity $(89.16 \mu \mathrm{g} / \mathrm{ml})$ was recorded for roots of $A$. santolinifolia followed by leaves $(68.14 \mu \mathrm{g} / \mathrm{ml})$. In low inhibitory concentration assay, the crude methanolic extracts showed significant inhibition against all tested microbes on different concentrations like $25 \mu \mathrm{g} / \mathrm{ml}, 50 \mu \mathrm{g} / \mathrm{ml}$, and $100 \mu \mathrm{g} / \mathrm{ml}$. The leaves extract of $A$. santolinifolia AsL showed MIC of $12.5 \mu \mathrm{g} / \mathrm{ml}$ for $B$. subtilis, a gram-positive bacterium, $50 \mu \mathrm{g} / \mathrm{ml}$ for gram positive bacteria $S$. aureus and $37.5 \mu \mathrm{g} / \mathrm{ml}$ for gram negative bacteria $P$. aeruginosa that is almost equal to the response of standard ciprofloxacin. Our current study revealed that Artemisia santolinifolia root (AsR) exhibited a significant antioxidant potential while AsL showed good antibacterial effect which is suggested to be used for treatment and management of different infectious diseases.
\end{abstract}

Keywords: Artemisia santolinifolia. Antioxidant Potential. Antibacterial Activity. Phytochemicals.

\section{Introduction}

Medicinal plants have intense effect on the health of animals and plants as well. The literature showed that medicinal plants are the main power of pharmaceutical companies. Most of the phytonutrients present in medicinal plants have antioxidant, antimicrobial, anti-inflammatory, phytotoxic and cytotoxic activities (Narayanaswamy and Balakrishn 2011; Balakrishn et al. 2013; Kotan et al. 2013). Richest source of crude drug are medicinal plants having high level of therapeutic agents. Traditional medicines are the most economical source of therapy to population.

Pakistan has a rich store of undiscovered Phyto-medicinal flora (Ahmad et al. 2015). Herbal medicines extensive use for health care has been noted and many natural products with novel healing properties are commercialized (Riaz and Rahman 2015). Plants medicinal properties have been investigated in the light of conversant scientific expansion all over the world, because of low toxicity and rich pharmacological applications (Vaquero et al. 2010). Different medicinal plants are used for the treatment of 
different diseases. Plant extracts and their varied formulations in the therapeutic utilization of many diseases in traditional remedy goes back to ancient time (Kamal et al. 2016). Artemisia is one of the diverse genera of family Asteraceae which is medicinally vital with many essential oils and secondary metabolites. Species of Artemisia are categorizing in to different groups based on their biological activities (Ahameethunisa and Hopper 2010). Natural extract of different synthetic compounds are phenolic rich compounds obtained from plants can boost the overall quality of food by reducing microbial growth and lipid oxidation (Zhang et al. 2016).

Many plant species and herbs preservative effect the presence of antimicrobial and anti-oxidative ingredients in their tissues. It is knowledgeable that between antioxidant status and incidence of human diseases, there is an inverse relationship such as neurodegenerative disease, atherosclerosis, aging and cancer (Morales et al. 2008). The goal of this work is the evaluation of antibacterial effect for $A$. santolinifolia against gram positive and gram-negative bacteria to standard antibiotics e.g., ampicillin and ciprofloxacin at different concentration.

\section{Material and Methods}

The research study was carried out in the laboratory of Pharmacognosy, Department of Pharmacy, University of Malakand Chakdara, Dir Lower, Pakistan.

\section{Collection and authentication}

Different species of Artemisia (Artemisia santolinifolia Turcz. Ex Besser) were collected from district, Dir lower, and were identified by flora of Pakistan and taxonomist in herbarium and Botanical Garden, Department of Botany, University of Malakand. The specimens were deposited in herbarium of University of Malakand under voucher, As4/6/18. Artemisia santolinifolia.

\section{Maceration}

After collection and identification, leaves, stem, and roots of the specimen was shade dried and weighed accordingly. After drying, the specimen were pulverized (powdered) and soaked in methanol for a prescribed period with occasional shaking (Ahmad et al. 2016). The specimen was filtered and reduced by rotary evaporator to produce a semisolid mass.

\section{Phytochemical analysis}

For the presence of bioactive compounds various chemical tests were carried out in each portion of all plant species by using standard procedures.

Test for tannins: Tannins presence in various fractions were determined by the following method of DOSS (2009). In a test tube $20 \mathrm{ml}$ of distilled water was boiled in $50 \mathrm{mg}$ of each fraction and was filtered. In each test tube $0.1 \%$ ferric chloride few drops were added, and color change was observed, by brownish green or a blue-black coloration indicates the presence of tannins.

Phenolic test: The plant extract is treated by the presence of phenols, which is proven by ferric chloride solution few drops and bluish black color formation according to Silva et al. (2017) procedure.

Test for saponins: According to Mir et al. (2013) standard procedure saponins were carried out in various fractions determination. In $20 \mathrm{ml}$ of distilled water boiled $20 \mathrm{mg}$ of each sample for five minutes in a water bath and filtered. $10 \mathrm{ml}$ of each filtrate were mixed with $5 \mathrm{ml}$ of distilled water and vigorously shaken for froth formation. In the froth 3 drops of olive oil was mixed, vigorously shaken and the formation of emulsion was observed.

Terpenoids test: According to Mir et al. (2013) presence of terpenoids in various fractions was determined. $2 \mathrm{ml}$ of chloroform was mixed with $5 \mathrm{ml}(1 \mathrm{mg} / \mathrm{ml})$ of each extract, and then to form a layer adds $3 \mathrm{ml}$ of concentrated $\mathrm{H}_{2} \mathrm{SO}_{4}$ carefully. The presence of terpenoids shown by reddish brown coloration of the interface. 
Flavonoid test: Take extract $25 \mathrm{mg}$ and $50 \mathrm{ml}$ of distal water and vigorously mix them and then add 2 to $3 \mathrm{ml} \mathrm{NaOH}$ solution and observed yellow coloration which indicate the flavonoids existence, according to standard protocol of Prabhavathi et al. (2016).

Protein test: According to Silva et al. (2017) procedure, take $5 \mathrm{mg}$ extract mixed with $5 \mathrm{ml}$ water and then add million's reagent show a foggy ash color surface is the indication of the presence of protein.

Steroid test: According to standard procedure followed by Islam et al. (2016), $5 \mathrm{mg}$ extract was mixed in $5 \mathrm{ml}$ chloroform and few drops of $\mathrm{H}_{2} \mathrm{SO}_{4}$ were added. The formation of reddish brown color indicates the presence of steroid.

Carbohydrate test: $5 \mathrm{mg}$ extract was mixed with $10 \mathrm{ml}$ distal water to form a solution then take $2 \mathrm{ml}$ solution $5 \mathrm{ml} \mathrm{H} \mathrm{SO}_{4}$ and few drops of Molisch's reagent give purple color indicate carbohydrate, according to Prabhavathi et al. (2016).

\section{Antioxidant activity}

Antioxidant potential of plant extracts was screened against DPPH and ABTS free radicals.

DPPH Activity: All parts (root, flower, leaf and stem) antioxidant activity was determined via 1, 1diphenyl-2-picrylhydrazyl assay (DPPH). $5 \mathrm{ml}$ of $0.004 \%(\mathrm{w} / \mathrm{v}$ ) solution of DPPH in methanol $50 \mu \mathrm{L}$ of 2.0 $\mathrm{mg} / \mathrm{mL}$ leaf extract (or $80 \%$ methanol as blank) was added. By using dark box, it was kept for 30 min of incubation. Plant parts which were leaves $(2.0 \mathrm{mg} / \mathrm{mL})$, roots $(2.0 \mathrm{mg} / \mathrm{mL})$ and stem $(2.0 \mathrm{mg} / \mathrm{mL})$ used for the same procedure. Ascorbic acid was used as standard. After $30 \mathrm{~min}$ of incubation, absorbance was measured at $517 \mathrm{~nm}$. The scavenging DPPH activity (\%) was calculated using the following formula.

$D P P H$ scavenging activity $(\%)=\left[\left(A_{0}-A_{1}\right) / A_{0}\right] \times 100$

Where the absorbance of the plant sample is $A_{1}$, and the control absorbance is $A_{0}$. All the plant extracts (root, leaf and stem) scavenging percentage was compared with positive controls (Oktay et al. 2003).

ABTS activity: On plant samples free radical scavenging activity was determined by ABTS via 2,2'azino-bis-3-ethylbenzthiazoline-6-sulphonic acid radical cation decolorization assay. Before use stored in the dark at room temperature for 12-16 h, ABTS cation radical was produced in water by the reaction between $7 \mathrm{mM}$ ABTS and $2.45 \mathrm{mM}$ potassium persulfate (1:1). With methanol ABTS++ solution was diluted to obtain an absorbance of 0.700 at $734 \mathrm{~nm}$. After the addition of $5 \mu \mathrm{l}$ of plant extract to $3.995 \mathrm{ml}$ of diluted ABTS·+ solution, after the initial mixing the absorbance was measured at $30 \mathrm{~min}$. In each assay an appropriate solvent blank was run. All the measurements were carried out five times. By using the formula calculated percent inhibition of absorbance at $734 \mathrm{~nm}$ :

$$
A B T S \cdot+\text { scavenging effect }(\%)=((A B-A A) / A B) \times 100(2)
$$

Where, the absorbance of $A B T S$ radical + methanol is $A B ; A A$ is absorbance of $A B T S$ radical + sample extract/standard (Rajurkar and Hande 2011).

Antibacterial screening of AsL, AsR and AsS from various parts of selected species, gram-positive and gram-negative bacterial strains were tested against, using method of agar well diffusion, about $20 \mathrm{ml}$ in sterile petri plates Mueller-Hinton Agar was poured and allowed to solidification. In the bacterial culture $\left(10^{6}\right.$ to $10^{8} \mathrm{CFU} / \mathrm{ml}$ ) the sterile cotton swab was dipped, and the agar plates were evenly inoculated by swabbing followed by the well's formation using sterilized cork-borer $(6 \mathrm{~mm}$ diameter). Pre labeled each well was filled with $100 \mu \mathrm{l}$ of various concentrations of flavones derivatives and allowed to diffuse by refrigerating for $30 \mathrm{~min}$. the plates were incubated at $37^{\circ} \mathrm{C}$ for $24 \mathrm{hrs}$. Each treatment was prepared by triplicate plates and excluding well average zone of inhibition was recorded. As a negative control DMSO (dimethyl sulphonic acid) was used. In zone of inhibition in millimeters $(\mathrm{mm})$ antibacterial potential was compared with standard antibiotic ampicillin and ciprofloxacin (Shoib et al. 2016).

\section{Minimum inhibitory concentration (MIC)}

Crude extract from various parts of selected species for MIC values MIC inhibiting growth of one or more of the above microorganism's inhibitions was again tested. Broth dilution technique determined the MIC values. Each compound stock solution was organized in dimethyl sulfoxide (DMSO) and a serially diluted to achieve the desire concentrations range. To each of pre-identified sterile test tube containing specific concentration of test compound, a standard volume was added of nutrient broth medium. To each tube was 
added the inoculum consisting of an overnight broth culture of microorganisms. The tubes were incubated for turbidity at $37^{\circ} \mathrm{C}$ for $24 \mathrm{hrs}$ and examined. No antimicrobial agent was added to a control tube and ciprofloxacin was used as standard. To stop the growth of bacteria the lowest concentration was regarded as MIC (Shoaib et al. 2016).

\section{Results and Discussion}

The research work was conducted in the Pharmacognosy lab, Pharmacy Department, university of Malakand. Phytochemical analysis, antioxidant and antibacterial activities worked out during the research study.

\section{Phytochemical screening}

Artemisia santolinifolia plant parts like root, leaves and stem possess metabolites like terpenoids, tannins, phenolics, flavonoids, carbohydrates, and steroids (Table 1). Proteins are absent in all parts (root, saponins leaves, and stem) of $A$. santolinifolia which suggest medicinal value of the specie. Some chemical compounds revealed by phytochemical characterization of the composition of the aqueous extracts (alkaloids, flavonoids, saponins, tannins, and steroids) for the required antifungal activities these are responsible (Salhi et al. 2017). Leaves of barley have maximum number of flavonoids sand saponin, and both composites have strong antioxidant activities. It also comprises magnesium which is important essential element, for glucose metabolism and insulin level optimization it serves as a co-factor (Qasim et al. 2016). In medicinal plants synthesized universally flavonoids are phenolic compounds due to the existence of carbonyl group that can induce antibacterial response (Umamaheswari and Sangeetha 2015) Phenolic compounds are present in Artemisia species proved by phenolic test currently (Silva-Alves et al. 2013). Pharmacological importance may be assumed, from the medicinal plant tannins were isolated against fungi and bacteria it is possessing remarkable toxic activity. Furthermore, special class of glycosides are saponins, considered as active antifungal agents and it have soapy characteristics (Salhi et al. 2017).

Table 1. Phytochemical screening of Artemisia santolinifolia.

\begin{tabular}{cccc}
\hline Phytochemicals & Leaves & Stem & Root \\
\hline Terpenoids & ++ & ++ & ++ \\
Tannins & ++ & ++ & ++ \\
Phenolics & ++ & ++ & ++ \\
Saponins & ++ & ++ & ++ \\
Flavonoids & ++ & ++ & ++ \\
Proteins & -- & -- & +- \\
Carbohydrates & ++ & ++ & ++ \\
Steroids & ++ & ++ & ++ \\
\hline
\end{tabular}

\section{Antioxidant activities}

The antioxidant activity of all parts (root, leaf, and stem) was determined via DPPH assay and ABTS assay. Ascorbic acid was taken as a standard. The result of antioxidant activity against DPPH and ABTS are given in Table 2. The table shows that maximum response of AsL is 51.05\% IC50.

The antioxidant DPPH activity also performed on different concentrations and the results shows different DPPH \% inhibition in which the highest \% inhibition is $(80.45 \pm 1.84)$ on $1000 \mu \mathrm{g} / \mathrm{ml}$ in AsS while the other samples like AsL $(77.11 \pm 1.14)$ and AsR $(77.23 \pm 1.66)$ also show high DPPH activity at a concentration of $1000 \mu \mathrm{g} / \mathrm{ml}$. At low concentration AsS at $62.5 \mu \mathrm{g} / \mathrm{ml}$ show the lowest DPPH activity which is (62.29 \pm 1.11$)$ while on same concentration the highest DPPH \% inhibition of AsR (49.19 \pm 1.32 ). While the ABTS percent inhibition also observed on different concentration in which the highest one in AsS (79.34 \pm 1.19$)$ and AsL (78.23 \pm 1.09$)$, and the lowest value is $(45.69 \pm 1.11)$ in AsR. It is to be noted by IC 50 calculated for all plant species obtained by ABTS assay were higher than those obtained by DPPH assay like ABTS highest mean value is $(89.16 \mu \mathrm{g} / \mathrm{ml}, 70.56 \mu \mathrm{g} / \mathrm{ml})$ and the lowest ABTS activity measured is $(68.14 \mu \mathrm{g} / \mathrm{ml})$ while DPPH highest activity is $(61.31 \mu \mathrm{g} / \mathrm{ml})$ and the lowest noted value is $(51.05 \mu \mathrm{g} / \mathrm{ml})$ (Figure 1$)$. 
Table 2. Antioxidant Assay of Artemisia santolinifolia with $\mathrm{IC}_{50}$ value.

\begin{tabular}{|c|c|c|c|c|c|c|}
\hline Name & Code & $\begin{array}{c}\text { Conc } \\
(\mu \mathrm{g} / \mathrm{mL})\end{array}$ & $\begin{array}{l}\text { DPPH Percent } \\
\text { inhibition }\end{array}$ & $\begin{array}{c}C_{50} \\
(\mu \mathrm{g} / \mathrm{mL})\end{array}$ & $\begin{array}{l}\text { ABTS Percent } \\
\text { inhibition }\end{array}$ & $\begin{array}{c}\mathrm{IC} \mathrm{C}_{50} \\
(\mu \mathrm{g} / \mathrm{mL})\end{array}$ \\
\hline \multirow{5}{*}{$\begin{array}{c}\text { Artemisia } \\
\text { santolinifolia }\end{array}$} & \multirow{5}{*}{ AsL } & 1000 & $77.11 \pm 1.14$ & & $78.23 \pm 1.09$ & \multirow{5}{*}{68.14} \\
\hline & & 500 & $72.19 \pm 0.84$ & & $74.83 \pm 1.10$ & \\
\hline & & 250 & $67.65 \pm 0.46$ & 51.05 & $68.51 \pm 1.14$ & \\
\hline & & 125 & $64.53 \pm 1.34$ & & $62.61 \pm 1.74$ & \\
\hline & & 62.5 & $57.78 \pm 0.45$ & & $56.21 \pm 1.34$ & \\
\hline \multirow{5}{*}{$\begin{array}{c}\text { Artemisia } \\
\text { santolinifolia }\end{array}$} & \multirow{5}{*}{ AsR } & 1000 & $77.23 \pm 1.66$ & & $77.12 \pm 1.05$ & \multirow{5}{*}{89.16} \\
\hline & & 500 & $70.39 \pm 1.01$ & & $71.34 \pm 1.34$ & \\
\hline & & 250 & $66.52 \pm 1.41$ & 61.31 & $63.45 \pm 1.87$ & \\
\hline & & 125 & $59.21 \pm 1.57$ & & $54.78 \pm 1.21$ & \\
\hline & & 62.5 & $49.19 \pm 1.35$ & & $45.69 \pm 1.11$ & \\
\hline \multirow{5}{*}{$\begin{array}{c}\text { Artemisia } \\
\text { santolinifolia }\end{array}$} & \multirow{5}{*}{ AsS } & 1000 & $80.45 \pm 1.84$ & & $79.34 \pm 1.19$ & \multirow{5}{*}{70.56} \\
\hline & & 500 & $78.17 \pm 1.04$ & & $70.24 \pm 1.86$ & \\
\hline & & 250 & $72.31 \pm 0.66$ & 53.61 & $68.29 \pm 1.37$ & \\
\hline & & 125 & $68.25 \pm 0.57$ & & $61.19 \pm 1.39$ & \\
\hline & & 62.5 & $62.29 \pm 1.11$ & & $59.24 \pm 1.37$ & \\
\hline \multirow{5}{*}{ Ascorbic acid } & \multirow{5}{*}{ AsA } & 1000 & $86.50 \pm 0.00$ & & $85.37 \pm 0.87$ & \multirow{5}{*}{$<1$} \\
\hline & & 500 & $86.33 \pm 0.16$ & & $84.52 \pm 0.22$ & \\
\hline & & 250 & $86.23 \pm 0.14$ & $<1$ & $83.67 \pm 1.39$ & \\
\hline & & 125 & $85.00 \pm 0.28$ & & $82.09 \pm 1.31$ & \\
\hline & & 62.5 & $84.00 \pm 0.28$ & & $80.11 \pm 1.01$ & \\
\hline
\end{tabular}

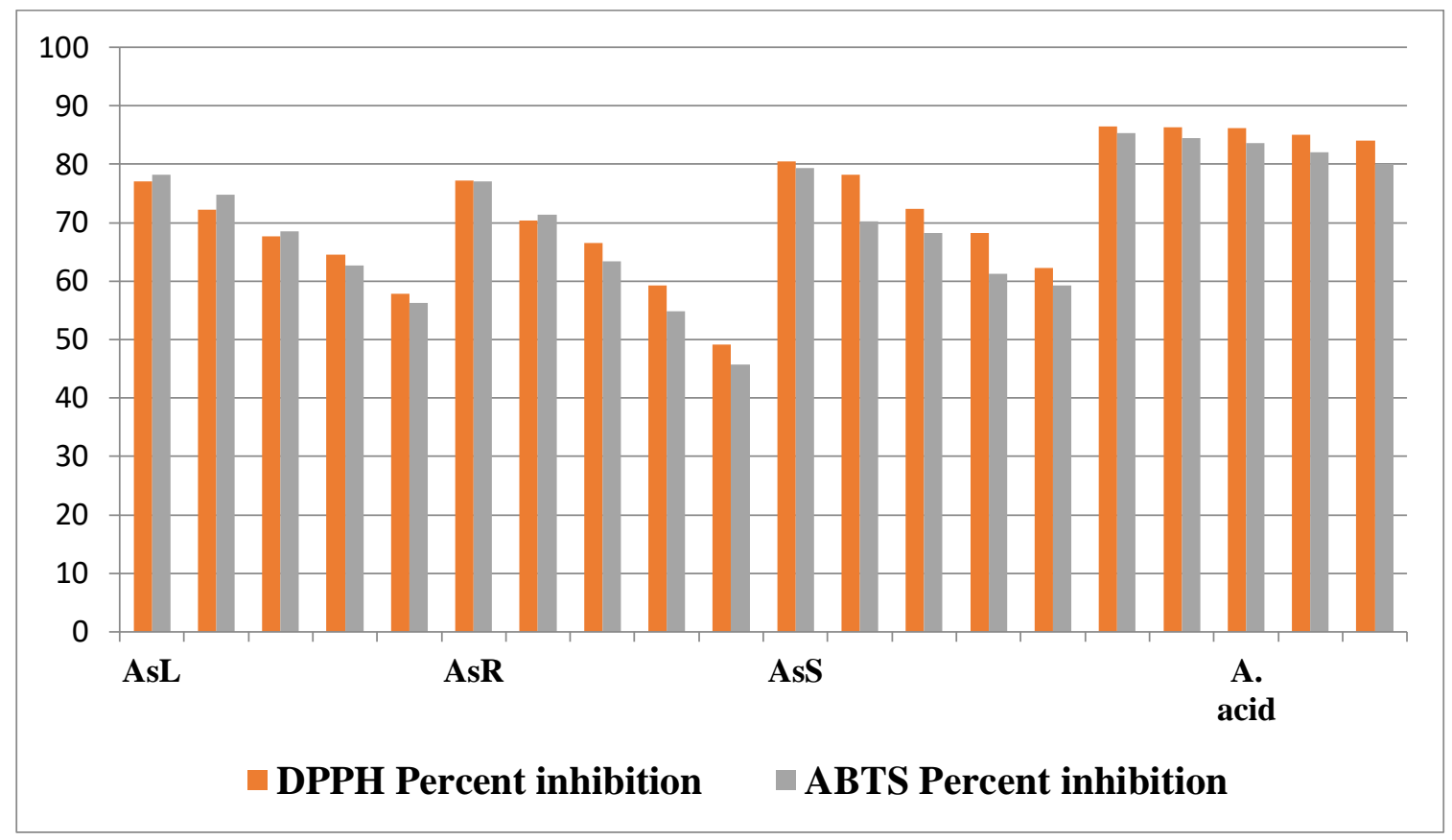

Figure 1. Antioxidant activities of Artemisia santolinifolia.

\section{Antibacterial activities}

Crude extract from various parts of selected species by using agar well diffusion method was tested against gram-negative and gram-positive bacterial strains. For each treatment plates were prepared and excluding well average zone of inhibition was recorded by using gram- negative and gram-positive bacteria at different concentration $(25 \mathrm{ml}, 50 \mathrm{ml}$ and $100 \mathrm{ml})$. At $50 \mu \mathrm{g} / \mathrm{ml}$ AsL zone of inhibition is $(23.21 \pm 1.14)$ and $(29.13 \pm 1.18)$ towards gram-positive bacteria $B$. subtalis and $S$. aureus respectively, while at same concentration gram-negative bacteria $P$. aeruginosa inhibition zone is $(25.35 \pm 1.33)$, the same gram-negative bacteria zone of inhibition at $100 \mu \mathrm{g} / \mathrm{ml}$ is $(29.18 \pm 1.72)$. The bacterial response which may be gram-positive or gram-negative the inhibition zone towards standard Ampicillin and Ciprofloxacin means values $(n=3)$ 
(29.09 \pm 1.78$),(38.15 \pm 1.51),(33.12 \pm 0.96),(31.35 \pm 2.01),(35.12 \pm 1.39)$ and $(32.01 \pm 1.05)$ respectively shows bacterial activity against different concentrations.

Up to the level of $200 \mu \mathrm{g} / \mathrm{ml}$ all the organisms are inactive in the organic solvents, it is shown by $L$. elasticus extracts. At a concentration of $25 \mu \mathrm{g} / \mathrm{ml}$ activity in the ethanol and methanol extracts is shown by both gram-negative and gram-positive organisms. All the tested organism, ethanol and methanol shows positive results in comparison with others (Krishnaveni et al. 2016). During anti-microbial activity, the higher quantity of essential oil ( $80 \mu \mathrm{L} /$ well) is needed for maximum zone of inhibition against all the microorganisms. Against Pseudomonas fluorescence (MTCC-664) and Bacillus subtilis (MTCC-2451) bacterial strains essential oils shown maximum and minimum zone of inhibition concentration, which indicate that essential oil of $A$. maritima Linn has inhibiting capacity to growth of both gram-negative and gram-positive bacterial strains. Because of Artemisia genus previous studies and present results it can be concluded that $A$. maritima Linn is an aromatic and higher altitude medicinal plants, many grams positive and gram-negative bacterial strains acts as a significant anti-microbial agent (Sharma et al., 2014).MIC of Artemisia. dracunculus Essential Oil was $6.25 \mathrm{mg} / \mathrm{mL}$ against $S$. aureus and B. subtilis. MIC value against $E$. coli VKPM-M17 was $50 \mathrm{mg} / \mathrm{mL}$, but $P$. aeruginosa was less susceptible to EO components and MIC value reached $150 \mathrm{mg} / \mathrm{mL}$. The antibioticresistant $E$. coli dhpo-pUCl8 strain possessed high sensitivity against the EO with $6.25 \mathrm{mg} / \mathrm{mL} \mathrm{MIC} \mathrm{value}$ (Table 3).

The action of EO was bactericidal. Tested yeasts were more susceptible against oil component, $\mathrm{MIC}=1.56 \mathrm{mg} / \mathrm{mL}$. The obtained results show that $A$. dracunculus EO can be useful for cosmetics, medicine, and food as antimicrobial natural agent. The present investigation revealed that gram-positive bacteria were more sensitive to it. The MIC of $A$. dracunculus EO was $6.25 \mathrm{mg} / \mathrm{mL}$ against $S$. aureus and B. subtilis. MIC values of oil under investigation against $E$. coli were $50 \mathrm{mg} / \mathrm{mL}$, but $P$. aeruginosa was less susceptible to EO components and MIC value reached $150 \mathrm{mg} / \mathrm{mL}$. The antibiotic- resistant $E$. coli was the most sensitive gramnegative microorganism against the investigated oil with $6.25 \mathrm{mg} / \mathrm{mL}$ MIC value. Tested fungi were more susceptible against oil components: MIC $=1.56 \mathrm{mg} / \mathrm{mL}$ against both tested yeasts. Thus, the MIC values determined are acceptable, effective, and the action of essential oils in this study was evaluated to be bactericidal (Petrosyan et al. 2018).

Table 4 illustrates the MIC $(\mu \mathrm{g} / \mathrm{ml})$ of crude extract from various parts of selected species against Gram-negative and Gram-positive bacteria. It is experiential that AsL possess inhibitory potentials at low concentration against all tested bacteria. The extract AsL showed MIC of $12.5 \mu \mathrm{g} / \mathrm{ml}$ for $B$. subtilis which is gram positive bacteria, $50 \mu \mathrm{g} / \mathrm{ml}$ for gram positive bacteria $S$. aureus and $37.5 \mu \mathrm{g} / \mathrm{ml}$ for gram negative bacteria $P$. aeruginosa.

Table 3. Antibacterial activities of Artemisia santolinifolia.

\begin{tabular}{|c|c|c|c|c|}
\hline \multirow{3}{*}{ Crude samples } & \multirow{3}{*}{$\begin{array}{l}\text { Concentration } \\
\qquad(\mu \mathrm{g} / \mathrm{ml})\end{array}$} & \multicolumn{3}{|c|}{ Zone of inhibition (mm) } \\
\hline & & \multicolumn{2}{|c|}{$\begin{array}{l}\text { Gram-positive } \\
\text { Bacteria }\end{array}$} & \multirow{2}{*}{$\begin{array}{c}\text { Gram-negative } \\
\text { Bacteria }\end{array}$} \\
\hline & & B. subtilis & S. aureus & \\
\hline \multirow{3}{*}{ AsL } & 25 & $19.32 \pm 2.61$ & $25.11 \pm 2.61$ & $23.09 \pm 0.91$ \\
\hline & 50 & $23.21 \pm 1.14$ & $29.13 \pm 1.18$ & $25.35 \pm 1.33$ \\
\hline & 100 & $21.09 \pm 1.82$ & $28.22 \pm 1.71$ & $29.18 \pm 1.72$ \\
\hline \multirow{4}{*}{ AsR } & 25 & $13.15 \pm 1.71$ & $16.19 \pm 1.48$ & $15.28 \pm 1.41$ \\
\hline & 50 & $15.13 \pm 2.11$ & $16.71 \pm 1.72$ & $16.09 \pm 2.08$ \\
\hline & 100 & $19.11 \pm 1.51$ & $18.19 \pm 1.51$ & $21.38 \pm 1.14$ \\
\hline & 25 & $10.81 \pm 1.71$ & $6.18 \pm 1.84$ & $7.09 \pm 2.13$ \\
\hline \multirow[t]{2}{*}{ AsS } & 50 & $13.39 \pm 2.21$ & $8.90 \pm 0.58$ & $8.27 \pm 1.04$ \\
\hline & 100 & $14.65 \pm 1.91$ & $8.27 \pm 1.41$ & $8.77 \pm 1.26$ \\
\hline Ampicillin & 10 & $29.09 \pm 1.78$ & $38.15 \pm 1.51$ & $33.12 \pm 0.96$ \\
\hline Ciprofloxacin & 10 & $31.35 \pm 2.01$ & $35.12 \pm 1.39$ & $32.01 \pm 1.05$ \\
\hline
\end{tabular}

All values are taken as mean $\pm \operatorname{SEM~}(n=3)$. 


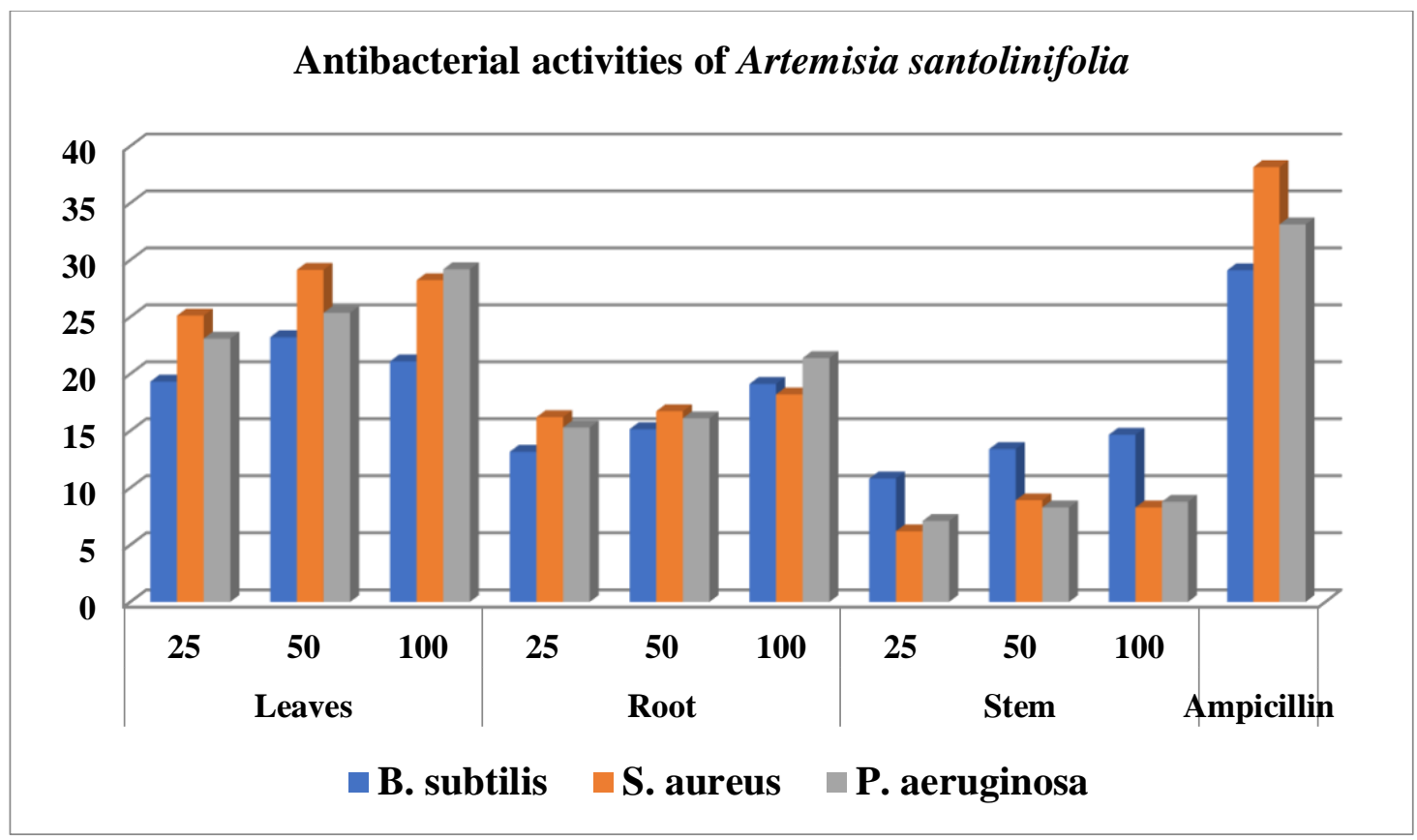

Figure 2. Antibacterial activities of Artemisia santolinifolia.

Table 4. The antibacterial activity MIC of selected Artemisia species crude extract.

\begin{tabular}{cccc}
\hline \multirow{2}{*}{$\begin{array}{c}\text { Crude extract samples from } \\
\text { various parts of selected } \\
\text { species }\end{array}$} & \multicolumn{2}{c}{$\begin{array}{c}\text { Gram-positive } \\
\text { Bacteria }\end{array}$} & MIC $(\mu \mathrm{g} / \mathrm{ml})$ \\
\cline { 2 - 4 } & B.subtilis & S.aureus & P. aeruginosa \\
\hline AsL & 12.5 & 50 & 37.5 \\
AsR & 62.5 & 50 & 25 \\
AsS & 100 & 100 & $>125$ \\
Ciprofloxacin & 6.25 & 6.25 & 6.25 \\
\hline
\end{tabular}

\section{Conclusions}

This study concluded that even through the availability of western medicines for simple and complicated diseases is available. Many people in the study area continue to depend on medicinal plants, atleast for the treatment of some simple diseases like cough, cold, fever, bites, headache, skin diseases and tooth infection. The experts of medicinal plants (Hakims) have good interaction with patients and this improves the quality of healthcare. Today traditional system of treatment was very old. Due to lack of interest among the younger generation as well as their tendency to migrate cities for beneficial jobs, there is a possibility of losing this wealth of knowledge soon. It is necessary to get hold of and preserve this traditional system of medicine by proper documentation. The present project, results offer a scientific basis for the traditional use of medicinal plants. However, further studies on medicinal plants are necessary to determine their active constituents. The antibacterial activity may be enhanced if active components of Artemisia species are purified. After phytochemical analysis different valuable chemicals are also identified, which also showed the importance of medicinal plants.

Authors' Contributions: NOWSHEEN, T.: acquisition of data, analysis and interpretation of data, and drafting the article; HAZRAT, A.: conception and design, and critical review of important intellectual content; SHAH, S.W.A.: conception and design, and critical review of important intellectual content; BIBI, S.: acquisition of data; BEGUM, A.: acquisition of data, analysis and interpretation of data, drafting the article; MUKHTIAR, M.: critical review of important intellectual content; KHAN, A.: acquisition of data. All authors have read and approved the final version of the manuscript.

Conflicts of Interest: The authors declare no conflicts of interest.

Ethics Approval: Not applicable. 
Acknowledgments: The authors would like to thank Sayed Wadood Ali Shah and Ali Hazrat for their support and facilitation in every aspect of research work.

\section{References}

Ahameethunisa, A.R. and Hopper, W. Antibacterial activity of Artemisia nilagirica leaf extracts against clinical and phytopathogenic bacteria. BMC Complementary Medicine and Therapies. 2010, 10, 6. https://doi.org/10.1186/1472-6882-10-6

Ahmad, A., Shinwari, Z.K., Hussain, J. and Ahmad, I. Insecticidal activities and phytochemical screening of crude extracts and derived fractions from three medicinal plants Nepeta Leavigata, Nepeta Akurramensis and Rhynchosia Reniformis. Pakistan Journal of Botany. 2016, 48, 24852487.

Ahmad, B., et al. Antimicrobial, Phytotoxic, Haemagglutination, insecticidal and antioxidant activities of the fruits of Sarcococca saligna (D. Don) Muel. Pakistan Journal of Botany. 2015, 47, 313-319.

Balakrishnan, B. and Ayyavoo, J. Evaluation of antioxidant activity of Clitoria ternatea and Alternanthera sessilis plant extracts using model system for yeast cells. African Journal of Basic \& Applied Sciences. 2013, 5(3), 134-138.

Doss, A. Preliminary phytochemical screening of some Indian medicinal plants. Ancient science of life. 2009, 29, 1-12.

Islam, et al. Qualitative and Quantitative Analysis of Phytochemicals in Some Medicinal Plants in Bangladesh. Journal of Chemical, Biological and Physical Sciences. 2016, 6, 530.

Kamal, M., et al. Anti-rheumatic potential of Pakistani medicinal plants: a review. Pakistan Journal of Botany. 2016, 48, 399-413.

Kotan, R., et al. Antibacterial activity of the essential oil and extracts of Satureja hortensis against plant pathogenic bacteria and their potential use as seed disinfectants. Scientia Horticulturae. 2013, 153, 34-41. https://doi.org/10.1016/j.scienta.2013.01.027

Krishnaveni, T., Valliappan, R., Selvaraju, R. and Prasad, P.N. Preliminary phytochemical, physicochemical and antimicrobial studies of Loranthus elasticus of Loranthaceae family. Journal of Pharmacognosy and Phytochemistry. 2016, 5, 7.

Mir, M.A., Sawhney, S. and Jassal, M. Qualitative and quantitative analysis of phytochemicals of Taraxacum officinale. Wudpecker Journal of Pharmacy and Pharmocology. 2013, 2, 1-5.

Morales, G., Paredes, A., Sierra, P. and Loyola, L.A. Antioxidant activity of 50\% aqueous-ethanol extract from Acantholippia deserticola. Biological research. 2008, 41, 151-155. http://dx.doi.org/10.4067/S0716-97602008000200004

Narayanaswamy, N. and Balakrishnan, K. Evaluation of some medicinal plants for their antioxidant properties. International Journal of PharmTech Research. 2011, 3(1), 381-385.

Oktay, M., Gülçin, i. and Küfrevioğlu, Ö.i. Determination of in vitro antioxidant activity of fennel (Foeniculum vulgare) seed extracts. LWT Food Science and Technology. 2003, 36, 263-271. https://doi.org/10.1016/S0023-6438(02)00226-8

Petrosyan, M., Sahakyan, N.Z. and Trchounian, A. Chemical composition and antimicrobial potential of essential oil of Artemisia dracunculus I., cultivated at high altitude Armenian landscape. Basic and applied research in microbiology, bioenergetics, and biotechnology. 2018, 52, 116121.

Prabhavathi, R., Prasad, M., and Jayaramu, M. Studies on qualitative and quantitative phytochemical analysis of Cissus quadrangularis. Advances in Applied Science Research. 2016, 7(4), 11-7.

Qasim, M., et al. Phytochemical potentials and medicinal uses of twenty-four selected medicinal plants from Swabi, Pakistan. Journal of Rural Development and Agriculture, 1(1), 49-58.

Rajurkar, N.S. and Hande, S. Estimation of phytochemical content and antioxidant activity of some selected traditional Indian medicinal plants. Indian Journal of Pharmaceutical Sciences. 2011, 73, 146. https://doi.org/10.4103/0250-474x.91574

Riaz, M. and Rahman, N.U. Biological activities of Rubus fruticosus L. Collected from Dir (L), Pakistan. Pakistan journal of Botany. 2015, 47, 127131.

Salhi, N., et al. Antifungal Activity of Aqueous Extracts of Some Dominant Algerian Medicinal Plants. BioMed research international. 2017, 2017, 7526291. https://doi.org/10.1155/2017/7526291

Sharma, V., et al. In vitro antimicrobial activity and GCMS analysis of essential oil of Artemisia maritima (Linn.) from Lahaul \& Spiti (Cold Desert) region of North-Indian higher altitude Himalayas. Journal of Medicinal Plants. 2014, 2(1), 45-52.

Shoaib, M., et al. Synthetic flavone derivatives. An antibacterial evaluation and structure-activity relationship study. Bulgarian Chemical Communications. 2016, 48, 414-421.

Silva, D., Abeysundara, G.O., and Aponso, M.M.W. Extraction methods, qualitative and quantitative techniques for screening of phytochemicals from plants. American Journal of Essential Oils and Natural Products. 2017, 5(2),29-32.

Silva-alves, K., et al. Estragole blocks neuronal excitability by direct inhibition of $\mathrm{Na}+$ channels. Brazilian Journal of Medical and Biological Research. 2013, 46, 1056-1063. https://doi.org/10.1590/1414-431X20133191

Umamaheswari, S. and Sangeetha, K.S. Anti-Inflammatory Effect of Selected Dihydroxyflavones. Journal of clinical and diagnostic research. 2015, 9(50, FF05-FF07. https://doi.org/10.7860/JCDR/2015/12543.5928 
Vaquero, M.R., Serravalle, L.T., De Nadra, M.M. and De Saad, A.S. Antioxidant capacity and antibacterial activity of phenolic compounds from argentinean herbs infusions. Food Control. 2010, 21, 779-785. https://doi.org/10.1016/i.foodcont.2009.10.017

Zhang, H., Wu, J. and Guo, X. Effects of antimicrobial and antioxidant activities of spice extracts on raw chicken meat quality. Food Science and Human Wellness. 2016, 5(1), 39-48. https://doi.org/10.1016/j.fshw.2015.11.003

Received: 22 April 2020 | Accepted: 27 July 2020 | Published: 13 October 2021

This is an Open Access article distributed under the terms of the Creative Commons Attribution License, which permits unrestricted use, distribution, and reproduction in any medium, provided the original work is properly cited. 